\title{
Effects of forest heterogeneity on occurrence and abundance of the scale-backed antbird, Hylophylax poecilinotus (Aves: Thamnophilidae), in the Amazon forest
}

\author{
Renato Cintra \& Jessica Cancelli
}

\author{
${ }_{1}$ Departamento de Ecologia, Instituto Nacional de Pesquisas da Amazônia. Caixa Postal 478, 69011-970 Manaus, Brasil. \\ E-mail: cintra@inpa.gov.br
}

\begin{abstract}
Recently, a significant number of studies on neotropical forest bird communities have focused on factors influencing their richness, abundance, and habitat selection. However, few of them have considered populations or individual species, and how habitat structure affects their distribution and abundance. In this study, we investigated how the combined effects of some forest structure components affect the occurrence and abundance of a resident bird species, the scale-backed antbird Hylophylax poecilinotus (Cabanis, 1847). We tested the null hypothesis of no difference between the variation in forest structure components at locations where birds occurred and at locations where they did not. In a pristine Terra Firme forest at the Ducke Reserve, Manaus, we recorded bird occurrence and abundance using mist nets in 56 transects (1 km long each) within a $9 \times 9 \mathrm{~km}$ trail grid covering 6400 ha. Also in the same 56 transects, we set 50 x 50 m plots and recorded the following seven components of forest structure and landscape: 1) canopy opening, 2) leaf litter, 3) tree abundance, 4) logs, 5) snags, 6) streams, and 7) elevation. We evaluated their effects on avian occurrence and abundance by using models of Multiple Logistic Regression (for bird occurrence) and Multiple Linear Regression (for bird abundance). The results suggested that $H$. poecilinotus occurred significantly more often in lowland areas, in areas located farther away from streams, and in areas bearing thicker leaf litter. Hylophylax poecilinotus was also more abundant in lowland areas and in areas located further away from streams. Overall, the results indicated that environmental heterogeneity produced by variation in forest structure components affects habitat use by this bird species in the Amazon forest.
\end{abstract}

KEY WORDS. Birds; micro-habitat structure; Terra Firme Forest.

RESUMO. Efeitos da heterogeneidade da floresta na ocorrência e abundância do rendadinho, Hylophylax poecilinotus (Aves: Thamnophilidae), na floresta amazônica. Uma quantidade significativa de estudos sobre comunidade de aves em florestas neotropicais tem recentemente se concentrado em fatores afetando a riqueza e abundância e seleção de habitat por elas. Entretanto, poucos têm considerado espécies individuais e como variações na estrutura do habitat afetam a distribuição das aves. Neste estudo nós analisamos como os efeitos combinados de alguns componentes de estrutura da floresta afetam a ocorrência e abundância de uma espécie de ave residente, o rendadinho Hylophylax poecilinotus (Cabanis, 1847). Nós testamos a hipótese nula de não diferença entre a variação nos componentes de estrutura da floresta nos locais de ocorrência das aves e locais onde elas não ocorreram na floresta. Para gerar informações da ocorrência e abundância do Rendadinho, nós usamos redes ornitológicas em 56 transectos de 1 km dentro de uma grade de trilhas cobrindo 6400 ha em floresta de terra firme na Reserva Ducke, Manaus. Foram utilizadas redes ornitológicas ao longo de 56 transectos, nos quais também foram colocadas parcelas de 50 × $50 \mathrm{~m}$ e registrados sete componentes de estrutura da floresta: 1) a abertura do dossel da floresta, 2) o folhiço, 3) a abundância de árvores, 4) os troncos mortos no chão e 5) os troncos mortos em pé, 6) a proximidade de igarapés e 7) a altitude. Os efeitos deles na ocorrência e abundância das aves foram avaliados usando-se modelos de regressão múltipla logística (para ocorrência das aves) e de regressão múltipla linear (para abundância de aves). Os resultados sugerem que $H$. poecilinotus ocorreu significativamente mais em áreas de baixio, em áreas de maior profundidade de folhiço, e em áreas distantes de igarapés. Hylophylax poecilinotus também foi mais abundante em áreas de baixio e em áreas distantes de igarapés. Os resultados indicam que a heterogeneidade ambiental produzida pela variação em componentes de estrutura da floresta afeta o uso do habitat por esta espécie de ave na floresta Amazônica.

PALAVRAS-CHAVE. Amazônia; estrutura de micro-habitat; Floresta de Terra Firme.

Revista Brasileira de Zoologia 25 (4): 630-639, December, 2008 
According to ecological theory, a key factor to describe the niche of bird species is the understanding of how habitat structure influences avian populations and communities (MacArthur et al. 1966, Martin 1985, Terborgh et al. 1990). The effects of habitat heterogeneity on birds have been investigated in terms of the relationships between variability of vegetation and diversity of avian species, which may be a consequence of niche availability (MacArthur \& MacArthur 1961, Martin 1985).

.It has been recognized that variation in habitat use are of considerable importance, both within and among species, and that they change over space and time, probably due to individual movement and population dispersion, but also to differences in habitat structure (KarR \& FreEMARK 1983, LoIselle \& Blake 1991, Cintra \& SanaiotTi 2005, Cintra et al. 2006, Banks $\&$ Cintra 2008). However, the mechanisms that determine habitat use by bird populations in tropical rainforests are still not well understood (TERBORGH 1985).

Studies on habitat use by birds in tropical rainforests have also focused on factors affecting richness and abundance of species and most of the studies on effects of vegetation on birds have concentrated on habitat partitioning by species (REMSEN \& Parker 1983, Terborgh 1985), and on the effects of vegetation structure on bird guilds or communities (PEARSON 1975, Howe \& Smallwood 1982, Terborgh et al. 1990, Loiselle \& Blake 1991). However, few studies have investigated how micro-habitat structure and resource availability affect individual species (but see Terborgh 1985, Cintra 1997).

For instance, it has been found that forest fragmentation and selective logging can affect bird populations and their community composition (JoHNS 1991, MASON 1996) but again, the effects of habitat structure itself have been scarcely considered. In addition, most studies have been undertaken at micro or meso spatial scales (PeARSON 1977, BierRegaARd 1990, Robinson \& Terborgh 1995, Borges \& Guilherme 2000, Borges 2004, Guilherme \& Cintra 2001).

In the Amazon forest, most of the bird species are resident and sedentary (BierregaArd 1990a, STOufFer \& BierregaArd 1995, CoHn-Haft et al. 1997). Therefore, because they have relatively high longevity (SNOW \& LILL 1974) and, as a consequence, can learn more about the environment, they may adjust their use of micro-habitat according to local variation in the forest structure.

Micro-habitat selection by birds and, ultimately, the bird guild and community composition may be affected by variation in many components of the forest structure, such as canopy opening, tree height, leaf litter, abundance of forest trees, presence of aquatic environment, among others (TERBorgh 1985, Cintra 1997, Cintra et al. 2006). For example, the increase in tree-fall gap areas as a consequence of selective logging produces an increase in the abundance of insectivores and nectarivores birds (Guilherme \& CinTra 2001). The forest leaf litter shows spatial variation in its abundance or depth, and that can affect the use of the forest floor by insectivore birds (PEarson 1975).
In this study, we investigate how forest heterogeneity influences the occurrence and abundance of an ant-following bird, the scale-backed antbird, Hylophylax poecilinotus (Cabanis, 1847), which is territorial, relatively rare localy (WILLIS 1977), yet widely distributed in the Amazon region (HiLty 2003). Although some aspects of the biology and behaviour of this species are relatively well described (see WiLLIs 1982), we still do not know much about its ecology. Mainly, we do not know how this bird species responds to local variation in forest structural components (micro-habitats). This bird species is inconspicuous and not commonly recorded, probably because there are so few tropical biologists to study it.

The variables or components of forest heterogeneity we selected for this study may be important because: I) Hylophylax spp. depend on shady understory for foraging, and areas with more trees could be more shady and attractive to Hylophylax spp.; II) the abundance of logs and snags may provide more area for foraging and nesting; III) Hylophylax spp. often forage on the ground (WILls 1982), and areas in the forest with more leaf litter may have higher arthropod abundance (ADIs 1988); iv) canopy openness allowing higher light incidence may increase plant production and attract more insects than shaded sites, increasing local abundance of food and influencing abundance of insectivorous birds (BANKS \& CINTRA 2008); V) sites near streams (igarapé) are more humid and may have higher abundance of arthropods than sites away from igarapés; and VI) elevation is directly related to soil components, which affect the whole vegetation in the area.

In this study, we investigated how the combined effects of these forest structure components affect the occurrence and abundance of a resident bird species, the scale-backed antbird, $H$. poecilinotus. During our activities in a long term project banding birds at Reserva Ducke, we have captured many individuals all over the area of the reserve. Since this bird species has relatively small territory, we believe that its captures in mist nets at certain location, may indicate that the bird was at his territory in that site, at the moment of his flight interception by the nets. Data obtained from these net captures (given that there were no recaptures, they were not considered) were used to verify the occurrence and abundance of $H$. poecilinotus in 56 areas inside the Reserva, and relate them to spatial variation in the forest structure in those areas. We tested the null hypothesis of no differences between the variation on forest structural components at locations where birds occurred and randomly selected locations in a pristine Central Amazon forest.

\section{MATERIAL AND METHODS}

\section{Study area}

The study was conducted between January, 2002 and July, 2004 , in the Reserva Ducke, which has 10,000 ha and is located $30 \mathrm{~km}$ from Manaus, Amazonas ( $\left.02^{\circ} 55^{\prime}-03^{\circ} 01^{\prime} \mathrm{S}, 59^{\circ} 53^{\prime}-59^{\circ} 59^{\prime} \mathrm{W}\right)$. The mean annual precipitation in the area is $2,286 \mathrm{~mm}$. Most of the rainfall is concentrated between November and 
May, and a dry season often occurs between June and October. The reserve is divided into two water drainage basins by a "continuous plateau" located in its center. The streams at the eastern side of the reserve run to the Amazon River tributaries, and streams on the western side drain to the Negro river tributaries (Ribeiro et al. 1999). The dominant vegetation is a Terra Firme primary tropical rainforest, which is pristine and is never seasonally inundated by river fluctuations. The soil is an oxisol, and small streams are abundant in the area, resulting in an undulated terrain of lowlands intercalated with plateaus reaching an elevation of up to $140 \mathrm{~m}$ (Ribeiro et al. 1999). Although, in 1995 , at least $50 \%$ of forest fragments were already extinct in Manaus due to the rapid growth and poor management of the city, the reserve is still connected to continuous forest.

\section{Biology of the study species}

The scale-backed antbird, Hylophylax poecilinotus is widely distributed in the Amazon region (HiLty 2003). According to Willis (1982), "It is a quiet, gray ghost of understory, seems to appear and disappear as if by magic".

Between July 1973 and August 1974, WiLLIs (1982) color banded and followed 28 birds of this species at the Reserva Ducke and estimated their territory size as 8.2 ha per pair, with their territories having centers $200-300 \mathrm{~m}$ apart. This bird often forages away from ant swarms, alone or in pairs, mostly at heights of between zero (ground) and four meters in the understory (WILLIs 1982). This bird perches vertically on juveniles and stems of small treelets from which it sallies capturing arthropod prey on the forest floor, lower foliage, or twig and tree bark surfaces. Hylophylax poecilinotus, an arboreal bird that walks or hops as it forages, was never observed using forest vegetation layers above three meters in height and was often seen foraging on the forest floor for insects. Hylophylax poecilinotus does not invade the territory of other conspecific individuals, even when following army ant swarms. Hylophylax poecilinotus normally follows any army ants in their territories, and can forage away from ants when no ants are available (Willis 1982). The most common foraging pattern, when these birds forage near army ants, is a quick sally to the ground to peck an arthropod and back to a perch, but the bird also makes short sallies to trunks, lianas and leaves above ground (WILlis 1982). Its prey items recorded at Reserva Ducke are roaches, spiders, ant larvae, centipedes, grasshoppers, and small lizards (gecko) (WILlis 1982). Hylophylax poecilinotus may have two or more breeding seasons per year at Manaus, and the nest (two reddish-violet eggs with dark streaks and flecks) can be built on the ground or in a low stub (see Willis 1982). After leaving the nests, juveniles stay with the parents for up to six weeks, however, after their independence the young never stay with their parents (Willis 1982).

\section{Bird surveys}

We used ornithological mist nets to capture individuals, to register the occurrence and abundance of $H$. poecilinotus. The birds were captured with 20 mist-nets (length of $12 \mathrm{~m}$, height of
$2.5 \mathrm{~m}$, and $2.5 \mathrm{~cm}$ mesh size) placed in a continuous line covering $240 \mathrm{~m}$. The net line began at the mid-points $(500 \mathrm{~m})$ of 56 transects (each of $1 \mathrm{~km}$ length) distributed along the nine parallel $9 \mathrm{~km}$ length trails (which run east-west) covering 6400 ha of the reserve. All trails were numbered and marked every $100 \mathrm{~m}$.

The mist-nets were opened between 6:00 am and 01:00 $\mathrm{pm}$, for two consecutive days in each $1 \mathrm{~km}$ transect. The captured birds were identified and marked with numbered aluminum bands (CEMAVE - Center of Bird Migration, IBAMA, Brazil). Bird linear dimensions (total body length, culmen, wing, tail, and tarsus length) and weight were taken using a caliper ( $1 \mathrm{~mm}$ precision) and Pesola spring scales $(0.1 \mathrm{~g}$ precision). To standardize the sampling effort, each mist net line represented our sample unit.

Bird song recordings were used to confirm the presence and absence of the bird species in the same transects where the mist nets were opened.

\section{Recording the forest structure components}

We established $50 \times 50 \mathrm{~m}$ plots at the same 56 sites (each transects of $1 \mathrm{~km}$ ) where mist nets were located. Within these plots, we quantified the following forest structure components and features of the landscape: 1) number of trees (diameter at breast height - $\mathrm{DBH}>10 \mathrm{~cm}$ ); 2) number of logs; 3) number of snags; 4) leaf litter depth; 5) percentage of canopy opening; 6) distance to the nearest stream (igarapé); and 7) elevation.

We used the number of trees $(\mathrm{DBH}>10 \mathrm{~cm})$, logs (diameter $>20 \mathrm{~cm}$ ), and snags, as a measurement of their abundance in the analysis. Litter depth was recorded by inserting a knife blade in the forest floor and counting the number of pierced dead leafs. We recorded the leaf litter depth on the four corners and at the center of 21 sub-plots of $1 \mathrm{~m}^{2}, 10 \mathrm{~m}$ equidistant one from another, with 20 sub-plots distributed along the sides and one at the center of each $50 \times 50 \mathrm{~m}$ plot. The mean value of the sub-plots was used in the analysis. We recorded forest canopy opening using a Spherical Crown Densiometer (Concave - Mode C - Robert E. Lemonn, Forest Densiometer, 5733 SE Cornell Dr, Bartlesville, OK, USA). We made four readings (north, south, east, and west) at the corners and center the plots. According to the instrument recommendations, we multiplied each reading by 1.04, and used the mean value in the analysis. Distance to the nearest stream and elevation was collected from a topographic map already available.

\section{Statistical analyses}

Pearson correlation matrix analyses were used to verify whether correlations among the independent variables (the forest structure components) were significant. The independent variables that were significantly correlated were used in different regression models.

We conducted multiple logistic regression analyses to investigate the effects of forest structure components on the occurrence of $H$. poecilinotus, because the dependent variable is categorical (bird presence $=1$ and bird absence $=0$ ). 
The effects of forest structure components (independent variables) on abundance of $H$. poecilinotus (dependent variable) was evaluated using models of multiple linear regression, and all statistical analysis were done using the program Systat (Wilkinson 1998).

\section{RESULTS}

\section{Variation in the forest structure components}

In the 56 plots, the mean abundance of forest trees $(>10$ cm DBH) was 135.3 (range 62-235), the mean abundance of logs was 11 (Range 3-38), and the mean abundance of snags was 5.1 (range 0-11). The mean leaf litter depth for the $1 \mathrm{~m}^{2}$ sub-plots ranged 1.4 and 4.8 layers, and for the plots, 3.4 layers. The mean percentage of canopy opening was $9.3 \%$ (range 2.6-19.4\%).

The mean elevation was $75.6 \mathrm{~m}$ (range 38.7-114.7 $\mathrm{m}$ ). The mean distance to the nearest stream (igarape) was $209.2 \mathrm{~m}$ (range 0-571 m), (Appendix 1).

\section{Occurrence of Hylophylax poecilinotus}

We captured 39 individuals of $H$. poecilinotus, which were present in $20(35.7 \%)$ of the sampling transects. Its abundance ranged from 0 to 4 individuals (Appendix 1). Hylophylax poecilinotus occurred in six (28\%) areas of lowlands and in 15 areas further away from streams. Hylophylax poecilinotus did not occur in the southeastern part of the reserve (Bolivia water drainage basin), and was more concentrated in the northern part of Reserva Ducke (Fig. 1).

The linear dimensions and weights of $\mathrm{H}$. poecilinotus are the following (mean \pm standard deviation (sample size): Body length (cm) $13.1 \pm 0.9$ (37); Culmen (cm) $1.6 \pm 0.3$ (37); Wing length (cm) $6.4 \pm 0.3$ (36); Tail length (cm) $4.2 \pm 0.6$ (37); Tarsus length (cm) $2.2 \pm 0.5$ (37); Weight (g) $16.4 \pm 4.1$ (38).

The results of the Pearson Correlation Matrix showed significant correlations between different independent variables (forest structure components) (Tab. I); therefore, they were separated into two different groups and included in two separated

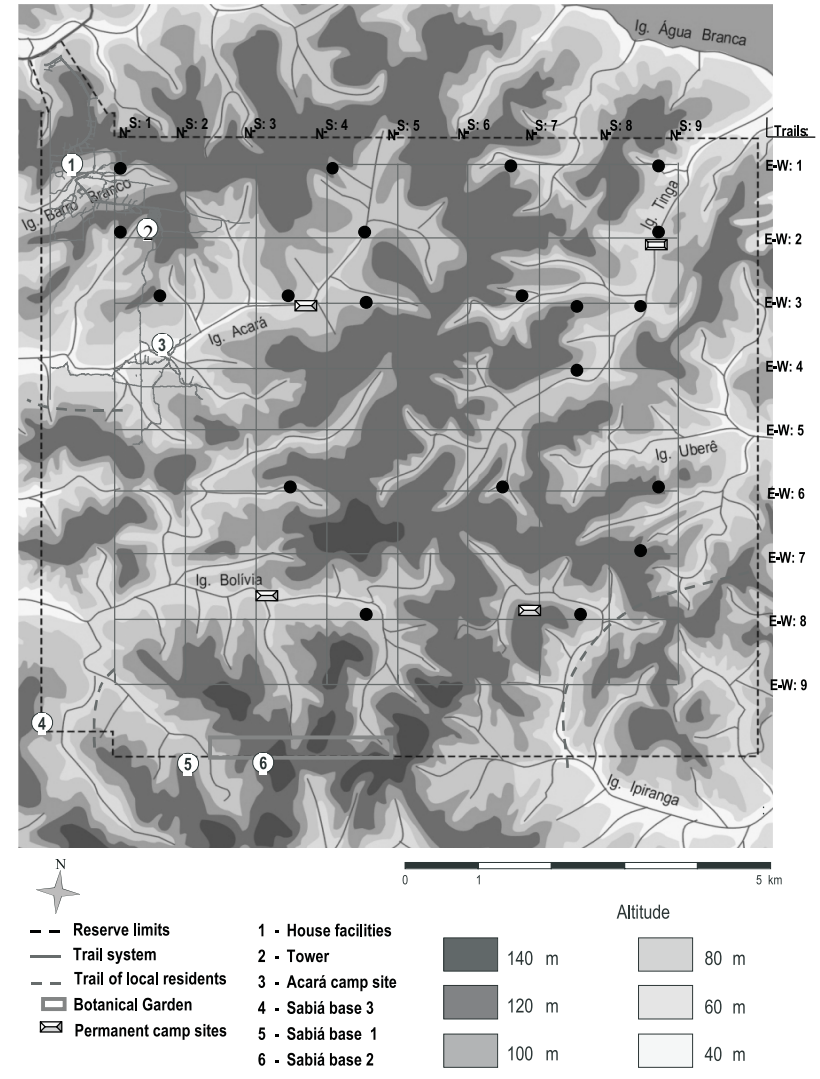

Figure 1. Occurrence of individuals of $H$. poecilinotus (filled circles) captured in mist nets at the Reserva Ducke, Manaus.

regression models, as following: Model -1 , Abundance of $H$. poicilinotus $=$ constant + abundance of logs + abundance of snags + mean leaf litter depth + distance to the nearest stream; Model - 2, Abundance of $H$. poicilinotus $=$ constant + abundance of trees + elevation + percentage of forest canopy opening.

Table I. Pearson correlation matrix for the forest structure components, forest tree abundance (TA), forest logs abundance (LA), snag abundance (AS), leaflitter depth (LD), elevation (ALT), proximity to streams (PS), canopy opening (CO) recorded in 56 areas at Reserva Ducke.

\begin{tabular}{lccccccc}
\hline & TA & LA & AS & LD & ALT $(\mathrm{m})$ & PS $(\mathrm{m})$ & CO $(\%)$ \\
\hline TA & 1.000 & & & & & & \\
LA & -0.137 & 1.000 & & & & & \\
AS & 0.173 & -0.309 & 1.000 & & & & \\
LD & 0.039 & 0.313 & -0.351 & 1.000 & & & \\
ALT (m) & 0.079 & -0.079 & 0.114 & -0.331 & 1.000 & & \\
PS (m) & 0.001 & 0.119 & 0.088 & -0.141 & $0.493^{*}$ & 1.000 & -0.150 \\
CO (\%) & 0.220 & $0.522^{*}$ & $-0.419^{*}$ & $0.533^{*}$ & -0.294 & 1.000 \\
\hline
\end{tabular}

* Statistical significance of $p<0.05$ resulting from the Bonferroni probability matrix used to evaluate how strong and significant were the correlations among the independent variables (forest structure components). 
The effects of forest structure components on the occurence of Hylophylax poecilinotus

Individuals of $H$. poecilinotus occurred significantly more often in lowlands (Multiple logistic regression analysis, $\rho^{2}=0.206$, $\mathrm{N}=56, \mathrm{~T}=-3.207, \mathrm{p}=0.001)$, in areas with thicker leaf litter $\left(\rho^{2}=\right.$ $0.245, \mathrm{~N}=56, \mathrm{~T}=2.113, \mathrm{p}=0.035)$ and in areas located further away from igarapes $\left(\rho^{2}=0.245, \mathrm{~N}=56, \mathrm{~T}=-2.634, \mathrm{p}=0.008\right)$.

The occurence of individuals of $H$. poecilinotus was not affected significantly by the abundance of trees $\left(\rho^{2}=0.206\right.$, $\mathrm{N}=56, \mathrm{~T}=-0.504, \mathrm{p}=0.614)$, abundance of snags $\left(\rho^{2}=0.206\right.$, $\mathrm{N}=56, \mathrm{~T}=0.659, \mathrm{p}=0.510)$, canopy opening $\left(\rho^{2}=0.206\right.$,
$\mathrm{N}=56, \mathrm{~T}=-0.669, \mathrm{p}=0.504)$, nor by abundance of logs $\left(\rho^{2}=0.245, \mathrm{~N}=56, \mathrm{~T}=-1.475, \mathrm{p}=0.140\right)$.

\section{The effects of forest structure components on the abundance} of Hylophylax poecilinotus

The abundance of $H$. poecilinotus was not significantly affected by the abundance of logs (Partials from Multiple linear regression analysis, $\left.\mathrm{R}^{2}=0.241, \mathrm{~N}=56, \mathrm{~T}=-0.882, \mathrm{p}=0.382\right)$, the abundance of snags $\left(\mathrm{R}^{2}=0.241, \mathrm{~N}=56, \mathrm{~T}=1.319, \mathrm{p}=0.193\right)$, the abundance of trees $\left(\mathrm{R}^{2}=0.209, \mathrm{~N}=56, \mathrm{~T}=-0.105, \mathrm{p}=0.917\right)$, and by the mean percentage of forest canopy opening $\left(\mathrm{R}^{2}=0.209\right.$, $\mathrm{N}=56, \mathrm{~T}=-1.221, \mathrm{p}=0.228)$, However, The abundance of indi-
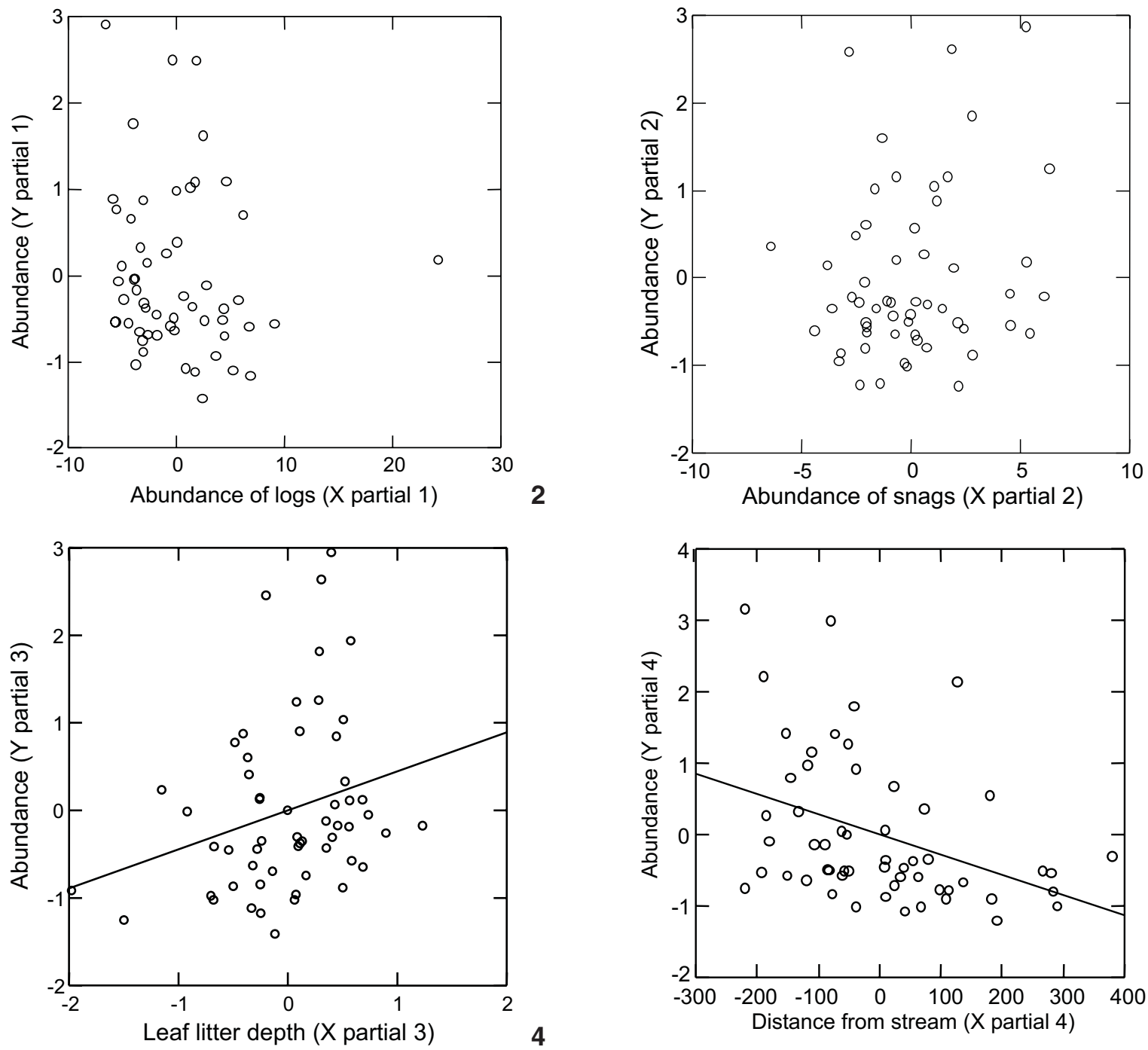

Figures 2-5. Partials of multiple linear regression on abundance of $H$. poecilinotus variation in relation to forest structure components: abundance of logs (2), abundance of snags (3), leaf litter depth (4), and distance to the nearest stream (5). Some numbers on the axis are negative because the partial regression represents the deviation of the expected results if all the other independent variables are kept at their observed means. 


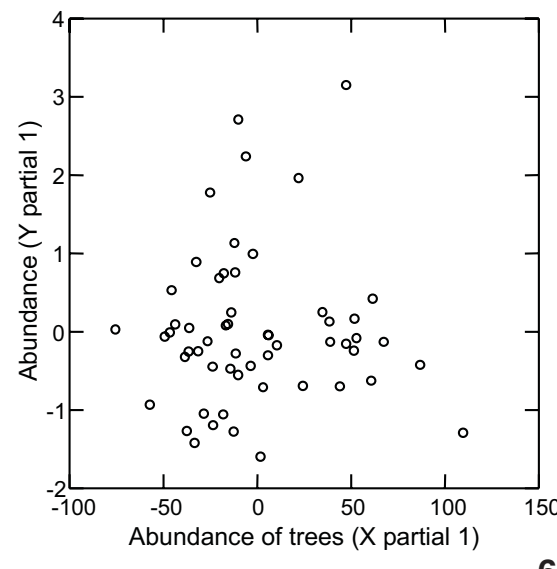

6
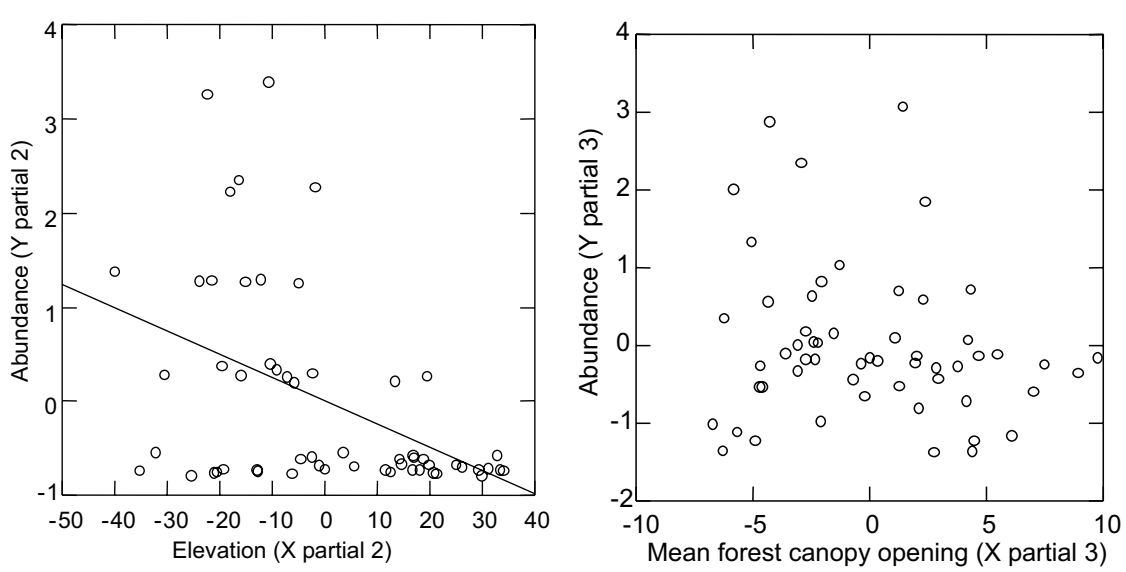

7

Figures 6-8. Partials of multiple linear regression on abundance of $H$. poecilinotus variation in relation to forest structure components: tree abundance (6), elevation (7), and mean percentage of canopy opening (8). Some numbers on the axis are negative because the partial regression represents the deviation of the expected results if all the other independent variables are kept at their observed means.

viduals of $H$. poecilinotus increased significantly with increasing in the leaf litter depth $\left(\mathrm{R}^{2}=0.241, \mathrm{~N}=56, \mathrm{~T}=1.961, \mathrm{p}=0.05\right)$, decreased further away from streams (igarapes) $\left(\mathrm{R}^{2}=0.241\right.$, $\mathrm{N}=56, \mathrm{~T}=-2.964, \mathrm{p}=0.005$; Figs $2-5$ ), and decreased with increasing in the elevation (Multiple partial regression $\mathrm{R}^{2}=0.209$, $\mathrm{N}=56, \mathrm{~T}=-3.671, \mathrm{p}=0.001$, Figs 6-8).

\section{DISCUSSION}

The presence or absence of a particular bird species in a given forest area can be affected by local forest heterogeneity, and this has led to a widespread conviction that variation in habitat structure is paramount in determining its occupancy by birds (MacArthur et al. 1962, Terborgh 1985).

Amazonian birds are generally more specialized in their foraging techniques, using narrower and having larger territories than temperate forest birds. It has been suggested that local variations in the forest structure may be important ecological factors affecting their habitat use (Orians 1969, Willis 1977, Remsen \& Parker 1983, Terborgh 1985, Karr et al. 1990, Terborgh et al. 1990, Cintra 1997, Borges et al. 1999, Cintra et al. 2006, BANKS \& CinTra 2008).

In general, the results of our study suggest that the environmental heterogeneity of the Amazon forest produced by the isolated or combined action of some forest structure components can affect the occurrence and abundance of the scalebacked antbird, $H$. poecilinotus. We found $H$. poecilinotus in higher abundance in areas with higher amount of leaf litter (see results). Hylophylax poecilinotus also forages on the ground; it seems that areas with abundant leaf litter may be more attractive to this bird species. Further investigations on the ecology of this species will be needed to explain why.

Studies relating bird communities to the structure of the Amazon forest in Ecuador (PEARSON 1977) showed that com- plexities and densities of foliage may influence populations using the same foraging technique. The abundance of other insectivorous birds such as woodcreepers, tyrant flycatchers and antbirds has also been found to be affected by the spatial variation in the leaf litter and by the abundance of arthropods (Pearson 1975, 1977), tree height (Cintra 1997), species differences in diet (Chapman \& Rosenberg 1991), and competition for food and foraging sites.

Human-disturbed forests in the Amazon region show a clear example of the importance of forest structure on the occurrence of birds. It is known that forest fragmentation and forest management through selective logging can affect bird occurrence and habitat use.

Stouffer \& BierregaARd (1995) found a striking reduction in both the number of individuals and number of species of understory insectivores after forest fragmentation and area isolation. BierregaARd \& Lovejoy (1989) also showed that insectivorous birds, which follow swarms of army ants, disappeared from forest fragments soon after their isolation from continuous forest. It has been also verified that $H$. poecilinotus abundance decreased in the 1 ha fragments, and that this species increased in the post-isolation data of the 10 ha fragments (HARPER 1989).

STOUfFer \& BierRegaARD (1995) also found that, H. poecilinotus was the most commonly netted bird species prior to forest isolation. Following the isolation of the area, they were in decline, and this species and most of the ant-follower birds began to return to forest fragments from the surrounding habitat matrix of secondary forest, mainly dominated by Cecropia trees. The habitat matrix is probably used temporarily as refuge, and may facilitate the use of forest fragments by ant followers.

When artificial disturbances increase and change the local forest structure, some bird populations also change in response to the modified environment (MASON 1996). In central 
Amazon, it was found that the local increase in forest canopy opening due to selective logging increased the abundance of nectarivorous and insectivorous birds (Guilherme \& Cintra 2001). These authors found more insectivorous birds using areas that had been logged 11 ago than in neighboring areas that had been logged four years before sampling. In addition an earlier study in our study area, investigated the effects of gap internal structure on bird community, in which the authors found an ecological gradient produced by tree-fall gap sizes influencing changes in insectivorous community composition, with significantly higher abundances of birds in the larger gaps (BANKS \& CINTRA 2008).

In the Amazon forest, unfortunately, few studies on communities have considered the effects of habitat structure on an individual bird species. However, it was demonstrated, both in areas of forest and savanna, that some insectivore species, at least from the Tyrannidae, Formicariidae and Dendrocolaptidae families, are influenced by the structure of vegetation (BANKS \& CINTRA 2008) and can select trees and perch positions for foraging (Willis \& ONIKI 1978, Willis 1972, 1979, 1982, Cintra 1997, CinTra et al. 2006).

Willis (1977) observed $H$. poecilinotus using areas of inclined terrain and plateaus and areas of secondary forest (capoeiras). The bird was foraging on the ground, using upward strikes to capture insects on the foliage surface. This species has also been recorded in some other habitats in the Amazon forest. Borges (2004), working in the Jau National Park, located about $150 \mathrm{~km}$ from our study area, recorded $H$. poecilinotus occurring in campinarana - small islands of open forests occurring in exposed sandy soils, with endemic plant species and lower diversity compared with those in predominant Terra firme forest (Prance 1996) -, Terra firme forest and Igapo forest.

We found $H$. poecilinotus occurring at higher abundance in lowland areas (Fig. 1), in areas further away from aquatic environments (streams), probably because of higher abundance of arthropods in these areas, but this needs further investigation. Neotropical forest birds are generally more sedentary (BIERREGAARD 1990), and because birds such as $H$. poecilinotus may have relatively high longevity, and may have enough time to learn about the forest environment, and therefore, develop preferences for areas with some combinations of forest structure components, which in turn affect their occurrence and abundance.

The lack of correlation between the occurrence and abundance of $H$. poecilinotus here analyzed and other forest structure components suggest that the factors influencing microhabitat use and habitat selection are complex and still need further investigation.

In central Amazonia, intensive bird surveys have reinforced beliefs that forest structure can also affect other bird species. For example, a recent study has showed that some of the same forest structure components studied here can affect the occurrence and abundance of two species of woodcreepers (CInTRA et al. 2006).
The results presented in this study need to be considered with caution because we did not intend to evaluate the entire spatial distribution of $H$. poecilinotus in the Reserva Ducke (therefore, spatial analyses was not used), but just broadly examine how it is influenced by forest structure in some areas in which the bird occurs compared with some that it does not occurs.

The knowledge of how birds use the forest may help us to understand why they select some types of micro-habitats. In the future, this type of information will be helpful to implement policy conservation efforts for bird conservation and to prevent the negative impacts of forest management activities on bird communities. However, further studies on other common and rare species are still needed to determine the influence of forest structure on bird distribution and abundance at the community level in the Amazon rain forest.

\section{ACKNOWLEDGEMENTS}

We thank Obed Barros, Sidnei Dantas, Marlison Ferreira, Lucas Mergulhão and Francisco M. Bezerra, for their competent field assistance in helping us with the mist nets and with measurements of forest structure components. Ricardo Romero has helped us to improve the quality of some figures. This study was supported by Instituto Nacional de Pesquisas da Amazônia, CNPq-PNOPg, CNPq-PELD.

\section{LITERATURE CITED}

ADIs, J.1988. On the abundance and density of terrestrial arthropods in Central Amazonian drylands forests. Journal of Tropical Ecology 4: 19-24.

BANKS, C. \& R.CinTrA. 2008. The hetogeneity of Amazonian treefall gaps and bird community composition. Ecotropica 14: $1-13$.

BierregaARD, R.O.1990. Species composition and trophic organization of the understory bird community in a Central Amazonian Terra Firme Forest, p. 217-236. In: A. GeNTry (Ed.). Four Neotropical Rainforests. New Haven, Yale University Press, p.627p.

BierregaArd, R.O. \& T.E. Lovejoy. 1989. Effects of forest fragments on Amazonian understory bird communities. Acta Amazonica 19: 215-241.

Borges, S.H. 2004. Species poor but distinct: bird assemblages in white sand vegetation in Jaú National Park, Brazilian Amazon. The Ibis 146: 114-124.

Borges, S.H. \& E. Guilherme. 2000. Comunidade de aves em um fragmento florestal urbano em Manaus, Amazonas, Brasil. Ararajuba 8: 17-23.

Borges, S.H.; A. Carvalhaes \& L. Henriques.1999. Local topography and understory bird distribution in a Central Amazonian site, Brazil. Brazilian Journal of Ecology 1: 21-25.

Chapman, A. \& K.V. Rosenberg.1991. Diets of four sympatric amazonian woodcreepers (Dendrocolaptidae). The Condor 93: 904-915

Revista Brasileira de Zoologia 25 (4): 630-639, December, 2008 
Cintra, R. 1997. Spatial Distribution and foraging tactics of tyrant flycatchers in two habitats in the Brazilian Amazon. Studies on Neotropical Fauna \& Environment 32: 17-27.

Cintra, R. \& T. Sanaiotti. 2005. Fire effects on the composition of a bird community in an Amazonian savanna (Brazil). Brazilian Journal of Biology 65: 683-695.

Cintra, R.; A.E. Maruoka \& L.N. NaKa. 2006. Abundance of two Dendrocincla woodcreepers (Aves: Dendrocolaptidae) in relation to forest structure in Central Amazonia. Acta Amazonica 36: 209-220.

Cohn-Haft, M.; A.WhitTaker \& P.C. Stouffer. 1997. A new look at the "species poor" central Amazon: the avifauna north of Manaus, Brazil. Ornithological Monographs 48: 205-235.

Guilherme, E. \& R. Cintra. 2001. Effects of intensity and age of selective logging and tree girdling on an understory bird community composition in Central Amazonia, Brazil. Ecotropica 7: 77-92.

Harper, L.H. 1989. The persistence of ant-following birds in small Amazonian forest fragments. Acta Amazonica 19: 249-263.

Howe, H.F. \& J. Smallwood. 1982. Ecology of seed dispersal. Annual Review of Ecology and Systematics 13: 201-228.

Hilty, S. L. 2003. Birds of Venezuela. Princeton, Princeton University Press, $2^{\text {nd }}$ ed., 878 p.

JoHNs, A.1991. Responses of Amazonian rain forest bird to habitat modification. Journal of Tropical Ecology 7: 417-437.

Karr, J.R. \& K.E. Freemark. 1983. Habitat selection and environmental gradients dynamics in the "stable" tropics. Ecology 64: 1481-1494.

Karr, J.R.; S.K. Robinson; J.G. Blake \& R.O. BierregaArd. 1990. Birds of four Neotropical forests, p.237-269. In: A. H. GENTRY (Ed.). Four Neotropical Rainforest. New Haven, Yale University Press, 627p.

Loiselle, B.A. \& J.G. Blake. 1991. Temporal variation in birds and fruits along an elevational gradient in Costa Rica. Ecology 72 (1): 180-193.

MacArthur, R. \& J.W. MacArthur. 1961. On birds species diversity. Ecology 42 (3): 594-598.

MacArthur, R.H.; J.W. MacArthur \& J. Preer. 1962. On bird species diversity. II. Prediction of bird census from habitat measurements. The American Naturalist 96: 167-174.

MacArthur, R.H.; H. Recher \& M. Cody. 1966. On the relation between habitat selection and species diversity. The American Naturalist 100: 319-332.

MarTin, T.E. 1985. Selection of second-growth woodlands by frugivorous migrating birds in Panama: an effect of fruit size and plant density. Journal of Tropical Ecology 1: 157-170.

Mason, D.1996. Responses of Venezuelan understory birds to selective logging, enrichment strips, and vine cutting. Biotropica 28: 296-309.
ORIANS, G.H. 1969. The number of bird species in some tropical forests. Ecology 50: 783-801.

Pearson, D.L. 1975. The relation of folice complexity to ecological diversity of three Amazonian bird communities. The Condor 77: 453-466.

Pearson, D.L. 1977. Ecological relationship of small ant birds in Amazonian bird communities. The Auk 94: 283-292.

Prance, G.T. 1996. Islands in Amazonia. Philosophical transactions of the Royal Society of London, Biological Sciences 351: 823-833.

Remsen Jr, J.V \& T.A. Parker III. 1983. Contribution of river created habitats to bird species richness in Amazonia. Biotropica 15: 223-231.

Ribeiro, J.E.L.S.; M.J.G. Hopkins; A. Vicentini; C.A. Sothers; M.A. Costa; J.M. Brito; M.A.D. Souza; L.H.P. Martins; L.G. LohmanN; P.A.C.L. Assunção; E.C. Pereira; C.F. Silva; M.R. Mesquita; L.C. Procópio. 1999. Flora da Reserva Ducke - guia de identificação das plantas vasculares de uma floresta de terrafirme na Amazônia Central. Manaus, Instituto Nacional de Pesquisas da Amazônia, 816p.

Robinson, S.K. \& J. Terborgh. 1995. Interspecific aggression and habitat selection by Amazonian birds. Journal of Animal Ecology 64: 1-11.

Snow, D.W. \& A. LiLl. 1974. Longevity records for some neotropical land birds. Condor 76: 262-267.

Stouffer, P.C. \& R.O. Bierregaard. 1995. Use of Amazonian forest fragments by understory insectivorous birds. Ecology 76 (8): 2429-2495.

Terborgh, J. 1985. Habitat selection in Amazonian birds, p. 311338. In: Cody M.L. (Ed). Habitat Selection in birds. New York, Academic Press,558p.

Terborgh, J.; S.K. Robinson; T.A. Parker III; C.A. Munn \& N. Pierpont. 1990. Structure and organization of an Amazonian forest bird community. Ecological Monographs 60: 213238.

WILKINSON, L. 1998. Systat: the system for statistics. Illinois, SYSTAT Inc. Evanston..

WILLIS, E. O. 1972. The behaviour of Plain-brown Woodcreeper, Dendrocincla fuliginosa. The Wilson Bulletin 81: 377-420.

Willis, E.O. 1977. Lista preliminar das aves da parte noroeste e áreas vizinhas da Reserva Ducke, Amazonas, Brasil. Revista Brasileira de Biologia 37 (3): 585-601.

WiLLIs, E.O. 1979. Behavior and ecology of two forms of Whitechinned Woodcreepers (Dendrocincla merula, Dendrocolaptidae) in Amazonia. Papeis Avulsos de Zoologia 33: 2766.

Willis, E.O. 1982. The behaviour of scale-backed antbirds. Wilson Bulletin 94: 447-462.

Willis, E.O. \& Y. ONIKI. 1978. Birds and army ants. Annual Review of Ecology and Systematics 9: 243-263.

Submitted: 16.XI.2007; Accepted: 26.XI.2008.

Editorial responsibility: Fernando Camargo Passos. 
Appendix 1. Data of abundance and occurrence of $\mathrm{H}$. poecilinota in 56 areas of Reserva Ducke. (A) Abundance of $\mathrm{H}$. poecilinota; (B) occurrence of $\mathrm{H}$. poecilinota; (C) forest tree abundance; (D) abundance of forest logs; (E) abundance of snags; (F) mean leaf litter depth; $(G)$ mean of canopy opening; $(H)$ elevation $(\mathrm{m})$; $(\mathrm{I})$ distance to the nearest stream $(\mathrm{m})$. * Position of the ornithological net lines on each transect along the trails corresponds to those in figure 1. In the first column, letters on the left are trail identification and values within parenthesis represent the section of the trail (transects) in which the $250 \mathrm{~m}$ ornithological net line was opened (see also figure 1).

\begin{tabular}{|c|c|c|c|c|c|c|c|c|c|c|}
\hline $\begin{array}{l}\text { Location and position of ornithological } \\
\text { net lines along the trails* }\end{array}$ & Date & A & B & $\mathrm{C}$ & $\mathrm{D}$ & $E$ & $\mathrm{~F}$ & G & $\mathrm{H}$ & 1 \\
\hline EW-1 (0-250 m) & $\operatorname{Jan} / 2002$ & 0 & 0 & 115 & 5 & 7 & 2.7 & 5.1 & 99.9 & 285 \\
\hline EW-1 (950-1200 m) & Mar/2002 & 0 & 0 & 141 & 9 & 5 & 1.4 & 5.0 & 108.8 & 142 \\
\hline EW-1 (2000-2250 m) & Mar/2002 & 1 & 1 & 82 & 10 & 7 & 2.8 & 3.1 & 110.8 & 500 \\
\hline EW-1 (3100-3350 m) & Mar/2002 & 4 & 1 & 110 & 8 & 6 & 3.9 & 6.2 & 71.2 & 71 \\
\hline EW-1 (5500-5750 m) & Aug/2002 & 0 & 0 & 188 & 6 & 2 & 3.9 & 13.0 & 63.4 & 71 \\
\hline EW-1 (6600-6850 m) & Aug/2002 & 2 & 1 & 187 & 10 & 4 & 4.1 & 13.1 & 69.1 & 214 \\
\hline EW-1 (7250-7500 m) & Aug/2002 & 1 & 1 & 115 & 7 & 2 & 4.0 & 13.2 & 44.2 & 35 \\
\hline $\mathrm{EW}-2(0-250 \mathrm{~m})$ & Feb/2002 & 0 & 0 & 83 & 6 & 4 & 3.2 & 4.3 & 92.5 & 0 \\
\hline EW-2 (100-350 m) & Feb/2002 & 0 & 0 & 151 & 5 & 11 & 3.0 & 4.7 & 82.8 & 285 \\
\hline EW-2 (2100-2350 m) & Feb/2002 & 3 & 1 & 121 & 9 & 0 & 3.0 & 4.8 & 114.7 & 571 \\
\hline EW-2 (3000-3250 m) & Mar/2002 & 0 & 0 & 122 & 11 & 7 & 3.5 & 5.9 & 78.1 & 339 \\
\hline EW-2 (4500-4750 m) & Nov/2002 & 0 & 0 & 111 & 21 & 1 & 4.0 & 16.5 & 92.0 & 228 \\
\hline EW-2 (5250-5500 m) & Aug/2002 & 0 & 0 & 119 & 18 & 4 & 3.9 & 15.0 & 96.8 & 357 \\
\hline EW-2 (6500-6750 m) & May/2002 & 3 & 1 & 151 & 9 & 4 & 3.9 & 12.0 & 87.4 & 464 \\
\hline EW-2 (7250-7500 m) & Aug, /2002 & 1 & 1 & 162 & 15 & 2 & 4.1 & 13.9 & 54.4 & 0 \\
\hline EW-3 (550-800 m) & $\mathrm{Mar} / 2002$ & 0 & 0 & 161 & 9 & 6 & 4.6 & 3.7 & 77.1 & 71 \\
\hline EW-3 (1600-1850 m) & Mar/2002 & 3 & 1 & 117 & 15 & 0 & 3.5 & 4.5 & 46.3 & 214 \\
\hline EW-3 (2250-2500 m) & Oct/2002 & 1 & 1 & 92 & 6 & 8 & 3.7 & 3.1 & 63.7 & 142 \\
\hline EW-3 (3250-3500 m) & Dec/2002 & 4 & 1 & 64 & 10 & 2 & 2.7 & 13.0 & 58.1 & 71 \\
\hline EW-3 (3500-3750 m) & Nov/2002 & 0 & 0 & 111 & 8 & 11 & 2.9 & 5.6 & 57.0 & 17 \\
\hline EW-3 (4500-4750 m) & Nov/2002 & 1 & 1 & 105 & 8 & 5 & 4.1 & 4.2 & 93.6 & 357 \\
\hline EW-3 (5500-5750 m) & May/2003 & 1 & 1 & 192 & 10 & 3 & 4.3 & 12.7 & 64.5 & 71 \\
\hline EW-3 (6500-6750 m) & May/2003 & 1 & 1 & 118 & 11 & 2 & 4.1 & 12.6 & 38.7 & 178 \\
\hline EW-3 (7500-7750 m) & May/2003 & 0 & 0 & 113 & 9 & 2 & 4.0 & 14.1 & 50.5 & 100 \\
\hline EW-4 (500-750 m) & Mar/2003 & 0 & 0 & 98 & 19 & 3 & 3.9 & 13.0 & 46.4 & 71 \\
\hline EW-4 (1600-1850 m) & Mar/2003 & 0 & 0 & 103 & 8 & 6 & 2.8 & 2.6 & 62.3 & 500 \\
\hline EW-4 (3500-3750 m) & Oct/2003 & 0 & 0 & 97 & 6 & 7 & 2.5 & 2.8 & 103.8 & 142 \\
\hline EW-4 (4300-4550 m) & Nov/2003 & 0 & 0 & 120 & 8 & 6 & 2.9 & 4.6 & 99.8 & 250 \\
\hline EW-4 (5250-5500 m) & Nov/2003 & 2 & 1 & 196 & 9 & 3 & 3.8 & 12.7 & 92.1 & 357 \\
\hline EW-4 (6500-6750 m) & May/2003 & 0 & 0 & 122 & 15 & 2 & 4.0 & 12.0 & 49.0 & 142 \\
\hline EW-5 (4250-4500 m) & Oct/2003 & 0 & 0 & 185 & 9 & 3 & 4.p & 11.3 & 95.3 & 128 \\
\hline EW-5 (3250-3500 m) & Nov/2003 & 0 & 0 & 201 & 9 & 2 & 3.3 & 19.4 & 98.1 & 128 \\
\hline EW-6 (1500-1750 m) & Aug/2003 & 1 & 1 & 113 & 17 & 4 & 4.2 & 14.7 & 52.6 & 214 \\
\hline EW-6 (2500-2750 m) & Aug/2003 & 0 & 0 & 130 & 16 & 9 & 3.9 & 14.0 & 65.6 & 178 \\
\hline EW-7 (500-750 m) & Apr/2003 & 0 & 0 & 117 & 13 & 2 & 3.5 & 15.2 & 45.9 & 9 \\
\hline EW-7 (1500-1750 m) & Jul/2003 & 0 & 0 & 135 & 17 & 4 & 3.7 & 13.5 & 74.7 & 286 \\
\hline EW-7 (2500-2750 m) & Aug/2003 & 0 & 0 & 113 & 14 & 2 & 4.p & 15.3 & 81.2 & 285 \\
\hline EW-7 (5500-5750 m) & Jul/2003 & 0 & 0 & 151 & 14 & 11 & 3.4 & 10.1 & 100.6 & 357 \\
\hline EW-7 (6500-6750 m) & Jul/2003 & 0 & 0 & 228 & 12 & 11 & 2.8 & 10.5 & 84.5 & 142 \\
\hline
\end{tabular}


Appendix 1. Continued.

\begin{tabular}{|c|c|c|c|c|c|c|c|c|c|c|}
\hline $\begin{array}{l}\text { Location and position of ornithological } \\
\text { net lines along the trails* }\end{array}$ & Date & $A$ & B & C & $\mathrm{D}$ & $E$ & $\mathrm{~F}$ & G & $\mathrm{H}$ & I \\
\hline EW-8 (2500-2750 m) & Apr/2003 & 2 & 1 & 87 & 22 & 4 & 3.8 & 15.4 & 56.2 & 285 \\
\hline EW-8 $(3500-3750 \mathrm{~m})$ & Apr/2003 & 0 & 0 & 108 & 17 & 3 & 3.8 & 14.6 & 50.2 & 142 \\
\hline EW-8 (5500-5750 m) & Jul/2003 & 2 & 1 & 211 & 11 & 5 & 2.8 & 9.9 & 97.5 & 285 \\
\hline EW-8 (6500-6750 m) & Jul/2003 & 0 & 0 & 185 & 14 & 11 & 3.3 & 8.7 & 40.5 & 142 \\
\hline EW-9 (6500-6750 m) & $\mathrm{Jul} / 2003$ & 0 & 0 & 188 & 9 & 8 & 3.p & 7.0 & 97.5 & 250 \\
\hline EW-9 (7350-7600 m) & Sep/2003 & 0 & 0 & 151 & 10 & 8 & 3.3 & 8.6 & 97.8 & 142 \\
\hline EW-9 (5250-5500 m) & Sep/2003 & 0 & 0 & 109 & 11 & 7 & 3.3 & 7.3 & 63.9 & 0 \\
\hline EW-4 (2250-2500 m) & $\operatorname{Jan} / 2004$ & 0 & 0 & 107 & 38 & 0 & 3.2 & 12.2 & 103.0 & 357 \\
\hline EW-5 (1500-1750 m) & $\operatorname{Jan} / 2004$ & 0 & 0 & 123 & 7 & 3 & 2.7 & 3.0 & 95.9 & 286 \\
\hline EW-5 (500-750 m) & $\operatorname{Jan} / 2004$ & 0 & 0 & 84 & 5 & 7 & 1.7 & 4.5 & 53.5 & 71 \\
\hline EW-5 (2500-2750 m) & $\operatorname{Jan} / 2004$ & 0 & 0 & 128 & 6 & 3 & 2.9 & 3.9 & 83.3 & 143 \\
\hline EW-1 (4000-4250 m) & $\operatorname{Jan} / 2004$ & 0 & 0 & 99 & 5 & 9 & 2.8 & 6.5 & 97.8 & 500 \\
\hline EW-6 (4500-4750 m) & Feb/2004 & 2 & 1 & 200 & 12 & 10 & 3.1 & 10.9 & 75.8 & 357 \\
\hline EW-6 (5500-5750 m) & Feb/2004 & 0 & 0 & 110 & 8 & 7 & 2.8 & 3.4 & 77.6 & 71 \\
\hline EW-6 (6500-6750 m) & Feb/2004 & 1 & 1 & 235 & 3 & 5 & 2.5 & 7.8 & 53.5 & 143 \\
\hline EW-6 (7500-7750 m) & Feb/2004 & 2 & 1 & 182 & 11 & 8 & 2.7 & 8.5 & 61.0 & 429 \\
\hline EW-7 (7500-7750 m) & Feb/2004 & 0 & 0 & 128 & 8 & 6 & 3.8 & 8.6 & 63.8 & 143 \\
\hline
\end{tabular}

